American Journal of Environmental Sciences 7 (1): 1-14, 2011

ISSN 1553-345X

(C) 2010 Science Publications

\title{
Hydrogeological Prognosis with Regard to Realisation of the New Colle Di Tenda Road Tunnel
}

\author{
${ }^{1}$ Cinzia Banzato, ${ }^{1}$ Massimo Vincenzo Civita, ${ }^{1}$ Adriano Fiorucci, \\ ${ }^{1}$ Bartolomeo Vigna and ${ }^{2}$ Salvatore Papale \\ ${ }^{1}$ Department of Environment and Geo-Engineering, \\ Politecnico di Torino DITAG, Corso Duca degli Abruzzi, \\ 2410129 Torino Italy \\ ${ }^{2}$ Azienda Nazionale Autonoma delle Strade Statali (ANAS) S.p.A., \\ Via Monzambano, 1000185 Roma Italy
}

\begin{abstract}
Problem statement: The doubling of Tenda pass road tunnel jointing SW France to Piedmont (Italy) was planned to penetrate a complicate rock structure in which several complex play an hydrogeologic role including carbonate-Karst aquifer between flysch impervious complexes. The main problem of the project is the presence of an hydraulic circulation feeding a spring of social and economic great importance discharging into a railroad tunnel below. Approach: The authors was charged by ANAS, Italian National Roads Authority, to execute a complete hydrogeologic prognosis of the situation that will be determinate by the excavation of the new tunnel and forecast as well as possible the hazard for the tapped spring. Results: Two years research have included a complete hydrogeologic and hydrochemical survey all the hypothesized structure feeding the spring, with several bore holes used as observation wells, the use of several monitoring device for the discharge and the chemical characters of spring, a lot of laboratory tests on cements and micro-cements and other materials used in waterproofing and sustain the rocks during the excavation and the concrete lining of the tunnel. Conclusion: The study ends with the evaluation of the vulnerability of the spring and the forecasting of contamination and depletion of the spring.
\end{abstract}

Key words: Colle di tenda, parallel monitoring, hydrogeological prognosis, road tunnel, carbonate aquifer, electrical conductivity, chemical-physical variations, depletion coefficient, human consumption, overlaid permeability, sulphate-bicarbonate-calcic facies

\section{INTRODUCTION}

With the prospect of doubling the road tunnel that, via Colle di Tenda, joins Italy and France, the National Roads Authority (ANAS) based in Rome asked the Dipartimento di Ingegneria del Territorio, dell'Ambiente e delle Geotecnologie (DITAG) of Politecnico di Torino to make the preliminary hydrogeological prognosis, based on existing information and on information gathered during the research project itself. The geographical location of the area under assessment is on the border between Italy (southern Piedmont) and France (Provence-Alpes-Côte d'Azur), at the Colle di Tenda pass, where there is an existing road tunnel and a railway tunnel (Fig. 1).

In agreement with its French counterpart, ANAS considered two initial approaches to the project:
- Widening of the existing road tunnel and excavation of a new tunnel (high altitude solution)

- Excavation of a new twin-tube tunnel (low altitude solution)

Table 1 shows the relevant data for the existing and planned tunnels.

Prior to consideration of problems of a purely geomechanical and specifically planning nature, choice of the best solution immediately appeared to be conditioned by problems of an applied hydrogeology and environmental nature, which, by the way, had already cropped up when the rail tunnel was excavated. Whatever the final choice, the new tunnel will in any case intercept a carbonate aquifer that feeds a series of important flows of groundwater, named "Sorgente di Tenda (Tenda Spring)" (Fig. 2), which were discovered during excavation of the railway tunnel (1889-1898).

Corresponding Author: Adriano Fiorucci, Department of Environment and Geo-Engineering, Politecnico di Torino DITAG, Corso Duca degli Abruzzi, 2410129 Torino Italy 


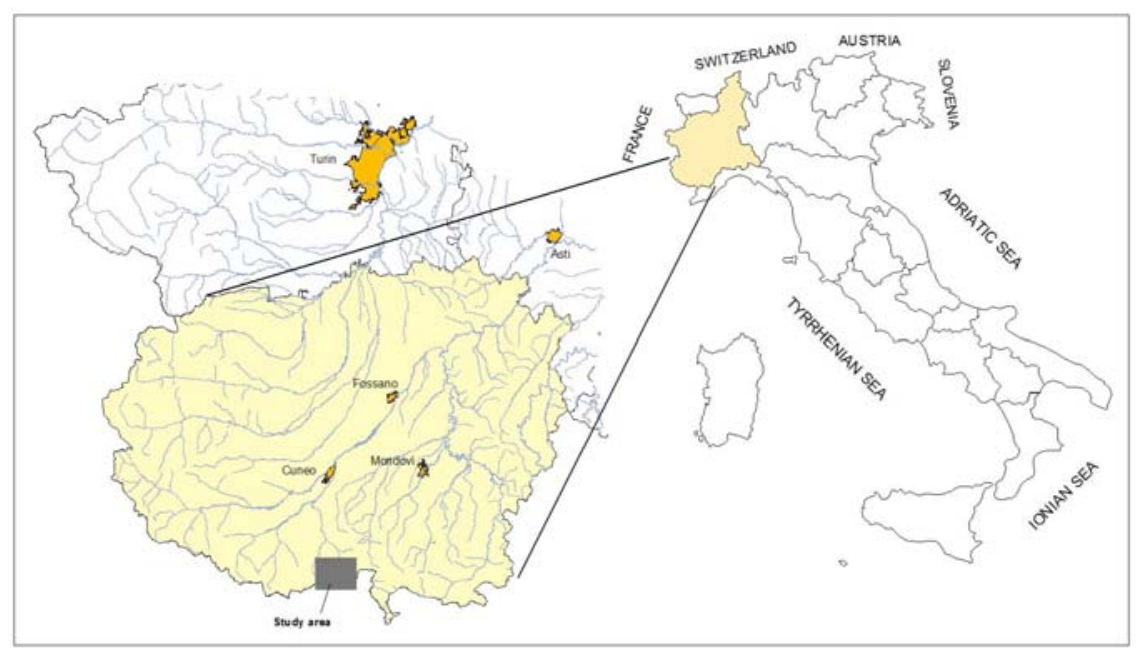

Fig. 1: Location of the area of interest

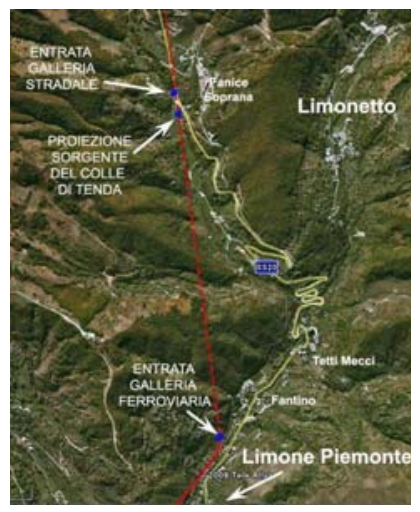

Fig. 2: Detail showing the area under examination. The aerial view shows the entrances to the two tunnels, the projection of the Sorgente di Tenda on the natural surface and the route of the rail tunnel

Table 1: Specifications for existing and planned tunnels

\begin{tabular}{|c|c|c|c|c|}
\hline Tunnel & $\begin{array}{l}\text { Altitude of } \\
\text { entrance on } \\
\text { Italian } \\
\text { side (m a.s.1.) }\end{array}$ & $\begin{array}{l}\text { Altitude } \\
\text { of entrance } \\
\text { on French side } \\
\text { (m a.s.l.) }\end{array}$ & $\begin{array}{l}\text { Section } \\
\left(\mathrm{m}^{2}\right)\end{array}$ & $\begin{array}{l}\text { Length } \\
\text { (m) }\end{array}$ \\
\hline Rail tunnel & 1037 & 1010 & & 8.099 \\
\hline Road & & & 34 & 3.195 \\
\hline Planned road tunnel & 1320 & 1276 & 63 & 3.268 \\
\hline
\end{tabular}

In 1990 the spring was tapped in the tunnel by the Langhe and Alpi Cuneesi Aqueduct; this infrastructure is very important for the social-economic development of a vast area, which has few other water resources suitable for human consumption and which supplies, along with some other sources, a population of over 100,000.

The purpose of the prognosis includes gaining an understanding of the hydrogeological situation of the entire rock mass covered by the works, in order to foresee both problems that may arise during construction due to the presence of water and also the possible effects that excavations may have on the important water resource that is tapped from the railway tunnel below. With this in mind, a series of operations have been planned, set up and carried out, the most important of which are as follows:

- General hydrogeological survey to identify the structure of the aquifer and the area supplying it

- Census of internal and external groundwater points with qualitative-quantitative monitoring

- Positioning of a number of well loggings and interpretation of resulting data as regards the waterbearing structure

- Assessment of the effects of excavation on the water resource, from the quantitative point of view and also because of the materials used for lining, waterproofing and whatever may be necessary due to the karst nature of the rock formations

This study summarises over three years' work and the results achieved, with completion of the prognosis.

\section{MATERIALS AND METHODS}

Hydrogeology and water-bearing structure of the area of interest: The principal stratigraphic units forming the area of interest fall between the upper Mesozoic and lower Cenozoic eras. To summarise as far as possible, ignoring losing any of the geological and hydrogeological information, Table 2 has been drawn up for use in comparison of the maps to be presented later on. 
Am. J. Environ. Sci., 7 (1): 1-14, 2011

Table 2: Hydrogeologic formations in Colle di Tenda

\begin{tabular}{|c|c|c|c|c|}
\hline $\begin{array}{l}\text { Hydrogeologic } \\
\text { complex }\end{array}$ & $\begin{array}{l}\text { Geological } \\
\text { era }\end{array}$ & $\begin{array}{l}\text { Lithological and deposition } \\
\text { characteristics }\end{array}$ & $\begin{array}{l}\text { Hydrogeological } \\
\text { characteristics }\end{array}$ & $\begin{array}{l}\text { Role of water } \\
\text {-bearing structure }\end{array}$ \\
\hline Detritic-moraine & Quaternary & $\begin{array}{l}\text { Silt, sandy silt, gravel, slope-type } \\
\text { drift deposits and headers. }\end{array}$ & $\begin{array}{l}\text { Relatively variable permeability, } \\
\text { from low values in silty } \\
\text { lithotypes to high in detritic. }\end{array}$ & $\begin{array}{l}\text { Secondary aquifer that interferes } \\
\text { with the future tunnel but not } \\
\text { with the Sorgente di Tenda. }\end{array}$ \\
\hline Upper Flysch & Eocene & $\begin{array}{l}\text { Alternations of prevalent shale } \\
\text { with local arenaceous intercalations. }\end{array}$ & $\begin{array}{l}\text { Generally very low permeability. } \\
\text { In highly fractured zones } \\
\text { permeability is distinctly higher. }\end{array}$ & $\begin{array}{l}\text { Above the upper Carbonate } \\
\text { formation, this is an important } \\
\text { overlaid permeability threshold } \\
\text { that gives rise to a thick karst } \\
\text { saturated zone that is part of the } \\
\text { water-bearing structure that feeds } \\
\text { the Sorgente di Tenda. }\end{array}$ \\
\hline Upper limestone & Jurassic-Eocene & $\begin{array}{l}\text { Stratified marly limestone, calcarenites, } \\
\text { cemented polygenic conglomerates } \\
\text { (Eocene); limestone and dolomite } \\
\text { limestone (Jurassic) }\end{array}$ & $\begin{array}{l}\text { Relatively high permeability } \\
\text { related to heavy fracturing. In } \\
\text { Eocene lithotypes, in general, } \\
\text { fracturing is lower but karstification } \\
\text { of the discontinuities is greater. }\end{array}$ & $\begin{array}{l}\text { Main aquifer feeding } \\
\text { the Sorgente di Tenda. }\end{array}$ \\
\hline Shale-evaporite & Triassic & $\begin{array}{l}\text { Polychrome shale, breccias, } \\
\text { Carniola, local chalky lenses, limestone } \\
\text { breccias and dolomite limestone layers }\end{array}$ & $\begin{array}{l}\text { Generally very low permeability with } \\
\text { the exception of the more fractured } \\
\text { horizons where permeability is greater. }\end{array}$ & $\begin{array}{l}\text { Aquifer linked to the main one } \\
\text { conditioning the chemical } \\
\text { properties of the water from } \\
\text { the Sorgente di Tenda. }\end{array}$ \\
\hline Lower Flysch & Eocene & $\begin{array}{l}\text { Pelite and shale with sandstone, } \\
\text { with dense stratification. }\end{array}$ & $\begin{array}{l}\text { Generally low permeability with the } \\
\text { exception of the fractured and } \\
\text { cataclastic horizons which often show } \\
\text { a degree of water circulation. }\end{array}$ & $\begin{array}{l}\text { Below the upper Limestone } \\
\text { formation and the Shale-evaporite } \\
\text { formation, this is an important } \\
\text { definite permeability limit that } \\
\text { conditions water circulation in } \\
\text { the main aquifer. }\end{array}$ \\
\hline Lower carbonate & e Triassic-Jurassic & $\begin{array}{l}\text { Limestone, marly limestone, } \\
\text { dolomitic limestone and dolomite. }\end{array}$ & $\begin{array}{l}\text { High permeability due } \\
\text { to karst and fracturing. }\end{array}$ & $\begin{array}{l}\text { Secondary aquifer feeding } \\
\text { a series of water inflows } \\
\text { involving the French section } \\
\text { of the rail tunnel. }\end{array}$ \\
\hline Evaporite & Triassic & $\begin{array}{l}\text { Thick masses of gypsum, anhydrite and } \\
\text { Carniole with highly variable geometries } \\
\text { with respect to thickness and extent. }\end{array}$ & $\begin{array}{l}\text { High permeability in sectors chara } \\
\text { scterised by relatively developed karst, } \\
\text { while in relatively compact and scarcely } \\
\text { fractured sectors permeability is relatively } \\
\text { low. Observations made in the existing road } \\
\text { tunnel show the chalk-anhydrite mass to be } \\
\text { a very low yielding aquifer while the Carniole } \\
\text { horizons show a significant water circulation } \\
\text { setting in the main discontinuities and in the } \\
\text { karst network. }\end{array}$ & $\begin{array}{l}\text { Secondary aquifer feeding a series } \\
\text { of water inflows with relatively } \\
\text { low flow rates and intercepted by } \\
\text { the current and planned } \\
\text { road tunnels. }\end{array}$ \\
\hline
\end{tabular}

The water-bearing structure of the area is conditioned by the presence of a main thrust surface, dipping to the NE, which divides the autochthonous sedimentary series of the Dominio Esterno Delfinese from the Falda Sub-Brianzonese. This surface is displaced by numerous sub-vertical tectonic discontinuities that significantly complicate the geometry of this contact. Moreover, within the Dominio Esterno Delfinese there are several discontinuity surfaces, also dipping towards NE, between the Flysch formation and the Evaporitic formation.

In the Falda Sub-Brianzonese succession the upper Carbonate formation, which contains the main aquifer, is in contact with the underlying Argillite-Evaporite formation concerned with the thrust plane and hence, characterised by considerable deformations with variations in thickness. This horizon conditions groundwater circulation towards the Sorgente di Tenda.

The upper Flysch formation, above the upper Carbonate formation, acts as an important overlaid permeability threshold that gives rise to a thick karst saturated zone that is part of the water-bearing structure that feeds the main spring. Figure 3 and 4 show the plan view and section of the mountainous massif, as taken from observations made in the current road tunnel.

The area feeding the spring is a narrow, straight NW-SE band, which goes from the deep Cabanaira valley to the Val Grande di Palanfrè, covering a total of about $8 \mathrm{~km}^{2}$. GIS processing (Civita et al., 1999) was applied to the HYDRAC simulation model (Civita et al., 1982) to calculate the potential balance. The infiltration contribution of the overall area was found to be $0.24 \mathrm{~m}^{3}$ sec 1 and hence only a little lower than the average flow rate for the spring, as measured between 01/01/2003 and $25 / 11 / 2003$ and amounting to $0.25 \mathrm{~m}^{3} \mathrm{sec}^{-1}$.

The subject under examination: the Sorgente di Tenda: In order to better understand the characteristics of the water-bearing structure that govern birth of the spring and the general hydrodynamics of the system, a number of continuous well logging cores were planned and drilled and subsequently fitted as monitoring wells (Table 3). 


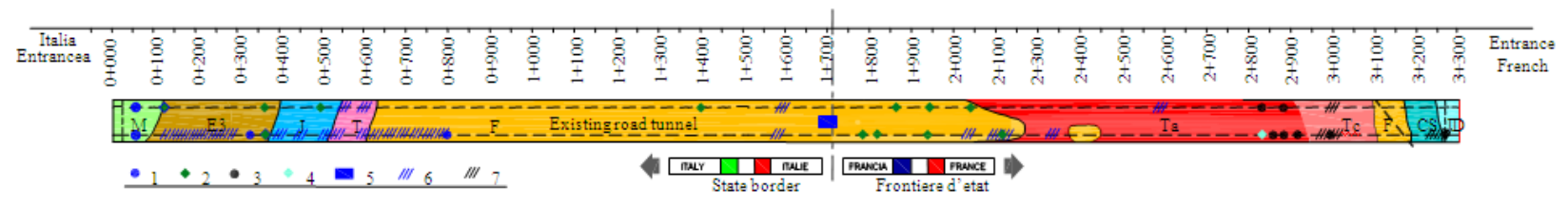

Fig. 3: Geological map of the current road tunnel with positions of the main water flows. (Source: ANAS)Modified and re-drawn. (1) Cold water, (2) cold seep, (3) hot water, (4) hot seep, (5) humid area on the base of the tunnel, (6) cold humid area, (7) hot humid area

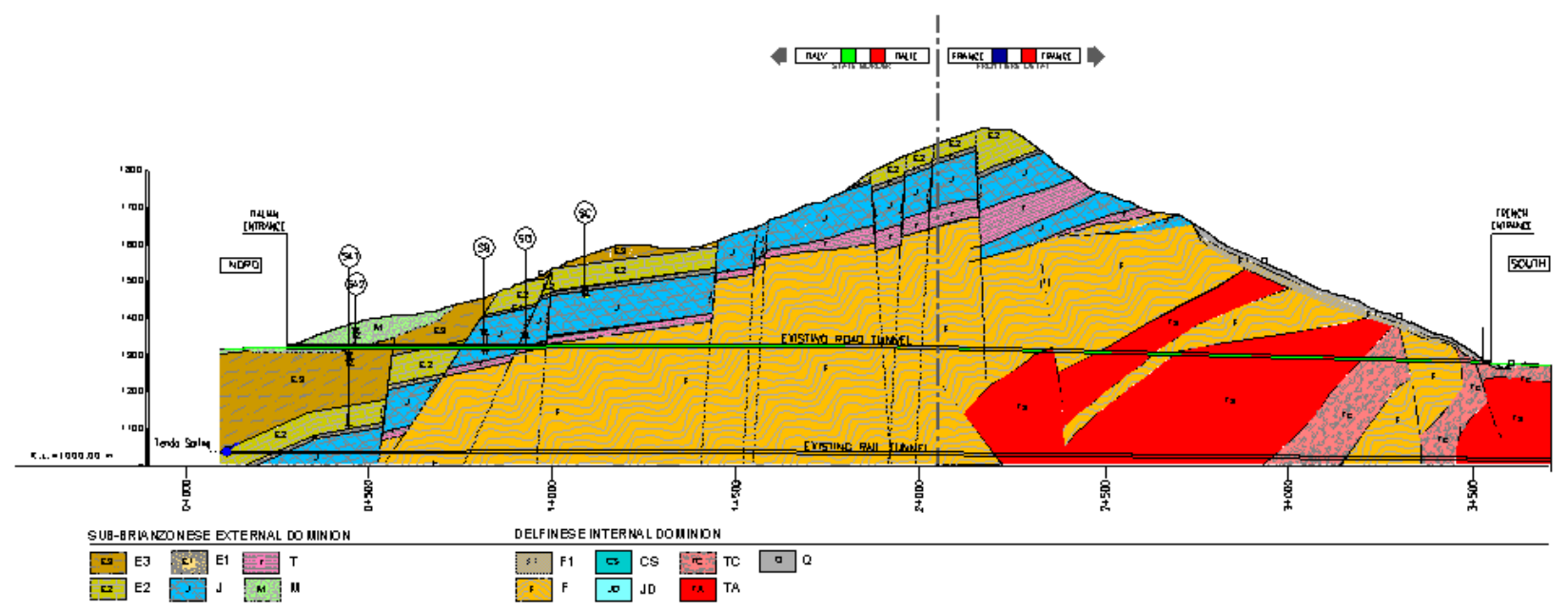

Fig. 4: Geological section of the current road tunnel with positions of the main water flows. (Source: Cuneo Province)-modified and re-drawn. (M) Morainic deposit, (E3) Flysch, (E2) Nummulitic limestone, (E1) Polygenetic conglomerate, (J) Limestone, (T) Dolomitic limestone-dolomite. (Q) Several kinds of deposit, (F1) Rework flysch, (F) Sandstone-pelitic flysch, (CS) Marl limestone, (JD) Limestone and dolomitic limestone, (TC) Clay and carniole, (TA) Gypsum and anhydrite

Table 3: Properties of the core drillings

\begin{tabular}{lllll}
\hline Drilling & Altitude $(\mathrm{m}$ a.s.1.) & Depth $(\mathrm{m})$ & Core sample & Posizione tratto filtrato (m) \\
\hline SB & 1453 & 150 & Continuous core sample & from 100-150 \\
SC & 1565 & 110 & Double sampler & from 85-100 \\
SA & 1385 & 280 & Continuous core sample & from 240-275 \\
SA2 & 1385 & 75 & & from 50-75 \\
SI3 & 1507 & 232 & Continuous core sample & \\
\hline
\end{tabular}

Due to violent inrushes (Fig. 6), study on summarises the information shown by the core drillings, while their positions are shown in Fig. 5.

Between the set points at 2489 and $3058 \mathrm{~m}$ from the northern entrance to the railway tunnel, a thick carbonate series was found, consisting of highly permeable Jurassic and Eocene limestone and giving flow rates of the order of $0.4 \mathrm{~m}^{3} \mathrm{sec}^{-1}$, on average. The aquifer is intercepted in the zone where the contact (permeability threshold) is situated, between the upper limestone formation and the upper Flysch formation. The rail tunnel was delayed for about 3 years until they managed to divert the various water flows into a channel that discharged into the Vermenagna stream. In
1990 a series of works, commissioned by the Langhe and Alpi Cuneesi Aqueduct Consortium, were initiated in order to tap the spring by means of a $60 \mathrm{~m}$ (approx.) drainage tunnel, which ran parallel to the rail tunnel (Fig. 7). The water is fed to a surge tank in Limone Piemonte. The spring is the main water resource of the Aqueduct Consortium, which distributes water to an extensive portion of Cuneo Province, covering the whole of the Langhe and Roero area and also to some municipalities in bordering Provinces (Savona and Asti). The relatively high altitude of the aforementioned surge tanks means that it is possible to transfer the water to the hills of Mombarcaro (approx $900 \mathrm{~m}$ a.s.1.). 
Am. J. Environ. Sci., 7 (1): 1-14, 2011

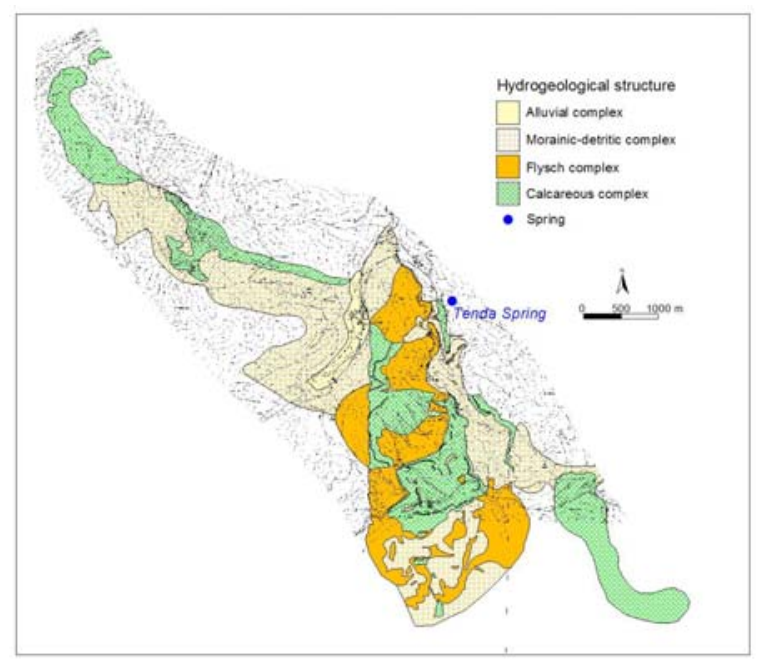

Fig. 5: Reconstruction of the hydrogeological structure of the $\mathrm{N}$ side of Col di Tenda based on surveyor's report

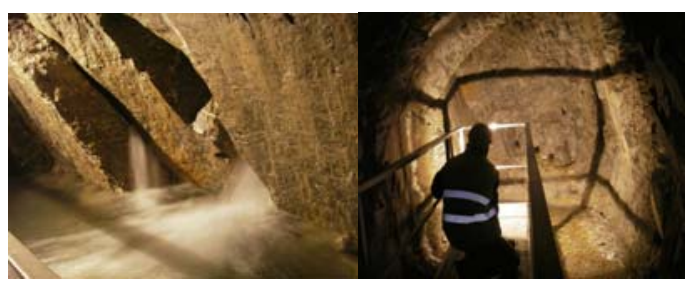

Fig. 6: On the left: Water flows from the fractured mass giving rise to the Sorgente di Tenda; on the right: Excavation face of the tapping tunnel

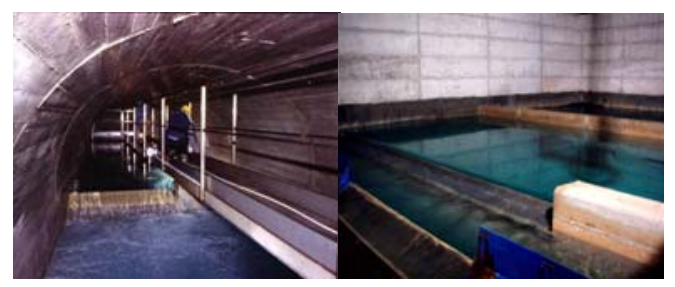

Fig. 7: On the left: the current tapping works; on the right: surge tank of aqueduct

Measurements of spring flow rate have been taken since 1895 , over differing periods, to obtain maximum and minimum values (Table 4). Italian National Railways (FS) technical staff also made an important discovery: the effect of precipitation is felt at the spring about 3-4 days after rain has started, while the flow begins to decrease after at least 5-6 days subsequent to the end of rain events.
From 2nd August 2004 until the present, an automatic sensor installed by the Langhe and Alpi Cuneesi Aqueduct has been taking continuous measurements of the water levels at the Sorgente di Tenda.

On 10.11.04 the Turin section of ANAS installed an automatic turbidity recorder at the same point and this is still in operation.

On 21.07.05, at the SI3 well logging, which had been fitted with an observation well, an automatic water level and temperature recorder was installed by DITAG.

At the spring tap in the Colle di Tenda rail tunnel, DITAG installed an automatic recorder for water level, temperature and specific electrical conductivity and began recording in December 2005. Measurements taken at the chosen monitoring point, directly at the spring tap, should be considered more reliable than those taken at the surge tank, which may be subject to interference due to operations in the surge tank itself.

As from 21.07.05, precipitation data were taken from the (Piedmont ARPA) Limone Pancani weather gauging station situated near Colle di Tenda.

\section{RESULTS}

Acquisition of all these records has made it possible to collate a considerable series of data regarding the hydrogeological structure of the whole zone and these will be compared and discussed in the following paragraphs. Figure 8 shows the recorded data for the daily flow rates of the spring together with the corresponding data for water conductivity and temperature.

For the same period, Fig. 9 shows the behaviour at the observation wells installed in the well loggings described above.

In order to verify the natural turbidity of the spring water, which is generally related to changes in flow rate at emergence and to evaluate the data in order to predict situations in which the carbonate aquifer may undergo stress as a result of construction of the new tunnel, in November 2004 a turbidity meter was installed at the aqueduct surge tank. Records taken over a period of more than one year, in the complete absence of interference with the aquifer, revealed an unusual situation (Fig. 10).

In general turbidity was nil, with the exception of periods in springtime when, after high flows due to snow melt, there was a significant increase in turbidity corresponding to the depletion stage of the flood itself.

The winter of 2006-2007, on the other hand, was characterised by very low snowfall and the subsequent springtime flood was mainly related to rainfall that did not give rise to turbidity phenomena in the spring water. 


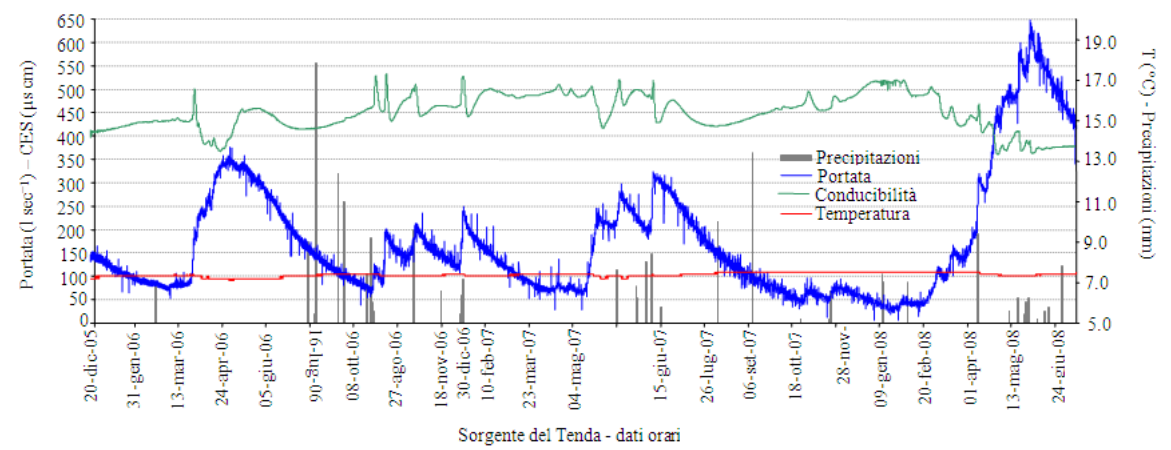

Fig. 8: Continuous monitoring data: flow rate, temperature and electrical conductivity of the spring water with precipitation for the feed area (Dec. '05-Jul. '08)

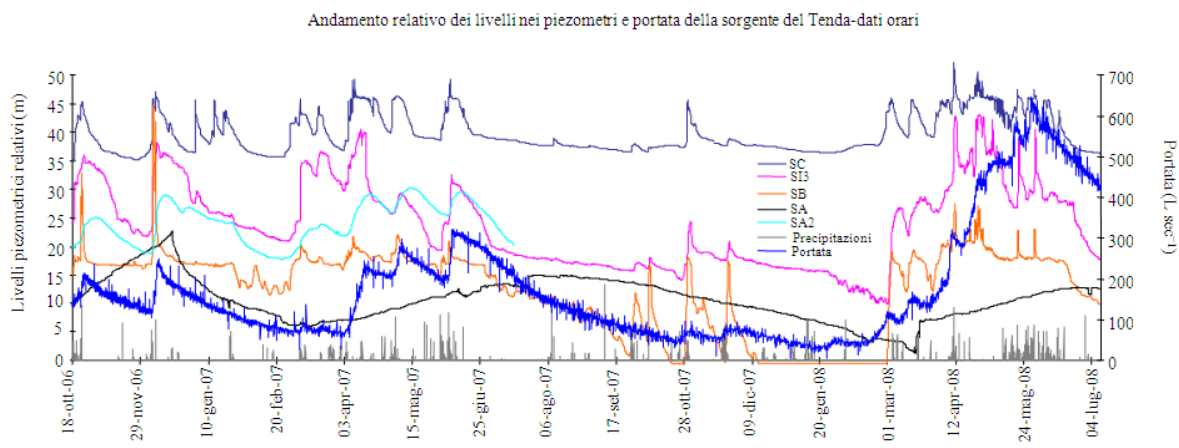

Fig. 9: Comparison of piezometric levels in observation wells, behaviour of spring flow rate and precipitation

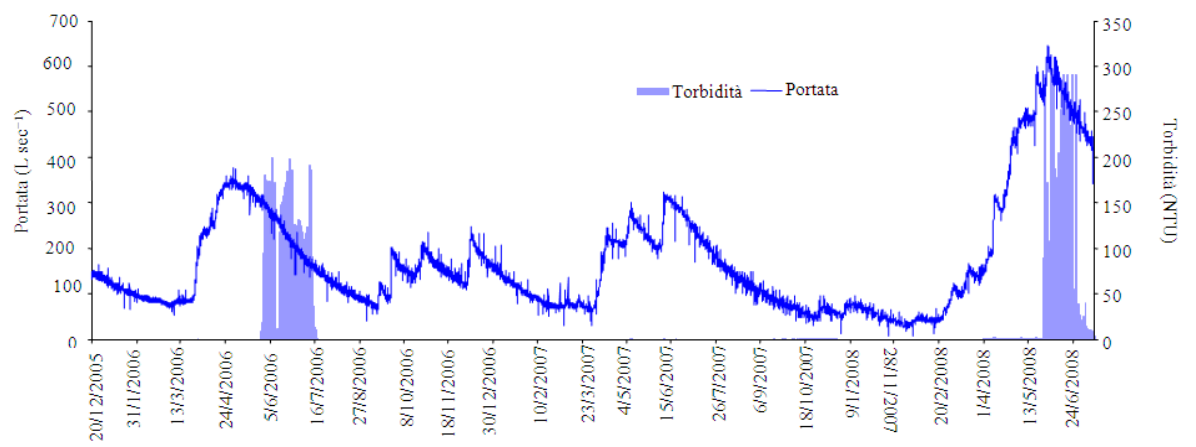

Fig. 10: Turbidity in spring water (Dec '05-Jul '08)

Aqueduct technical staff also noted visible turbidity in the water, reporting the arrival of whitishcoloured water. It is not easy to interpret these phenomena, both because they do not always occur after high flow events and also because, when they do occur, they may coincide with or be delayed with respect to peak flows. The most acceptable hypothesis leads one to think that arrival of turbidity is mainly due to snow melt characterised by modest but continuous input over very long periods. The delays with respect to peak flood could be related to the hydrodynamic characteristics of the aquifer and to the magnitude of the infiltration contribution.

This interpretation is supported by two marker tests on the carbonate aquifer. A significant amount of Tinopal CBS-X was injected under pressure into the well loggings equipped with observation wells (SI3 and SB) and this was followed by continuous readings at the spring using a G-Gun Fluorometer that was able to measure tracer content directly on site, at programmable intervals, detecting values of the order of $0.05 \mu \mathrm{g} \mathrm{L}^{-1}$. 
Am. J. Environ. Sci., 7 (1): 1-14, 2011

Table 4: Previous records of flow rate of the Sorgente di Tenda

\begin{tabular}{llllll}
\hline Measurement period & $\mathrm{Q}_{\max }\left(\mathrm{m}^{3} \mathrm{sec}^{-1}\right)$ & Records & $\mathrm{Q}_{\min }\left(\mathrm{m}^{3} \mathrm{sec}^{-1}\right)$ & Records & Source \\
\hline $1895-1903$ & $0.6 \div 0.7$ & May-June & $0.3 \div 0.4$ & Jan-March & FS \\
$1903-1914$ & 0.84 & --- & 0.21 & -- & FS \\
$1929-1931$ & 0.94 & June 1929 & 0.25 & Jan. 1931 & U.I. Po \\
$1959-1960$ & 0.95 & May 1960 & 0.32 & March 1960 & Provincia di Cuneo \\
$1999-2000$ & 0.41 & June 2000 & 0.12 & March 1999 & ACALAC \\
2003 & 0.38 & May 2003 & 0,13 & Sep. 2003 & DITAG Politecnico di Torino \\
\hline
\end{tabular}

Note: FS = Italian State Railways; U.I. Po = ACALAC = Consorzio per l'Acquedotto delle Langhe e delle Alpi Cuneesi (Aqueduct Consortium)

Table 5: Results of chemical analysis of the samples taken from the Sorgente di Tenda at different times.

\begin{tabular}{llllllcll}
\hline Sampling date & $\mathrm{Ca}^{2+}\left(\mathrm{mg} \mathrm{L}^{-1}\right)$ & $\mathrm{Mg}^{2+}\left(\mathrm{mg} \mathrm{L}^{-1}\right)$ & $\mathrm{Na}^{+}\left(\mathrm{mg} \mathrm{L}^{-1}\right)$ & $\mathrm{K}^{+}\left[\left(\mathrm{mg} \mathrm{L}^{-1}\right)\right.$ & $\mathrm{Cl}^{-}\left(\mathrm{mg} \mathrm{L}^{-1}\right)$ & $\mathrm{SO}_{4}^{2-}\left(\mathrm{mg} \mathrm{L}^{-1}\right)$ & $\mathrm{HCO}_{3}^{-}\left(\mathrm{mg} \mathrm{L}^{-1}\right)$ & $\mathrm{NO}_{3}^{-}\left(\mathrm{mg} \mathrm{L}^{-1}\right)$ \\
\hline $15 / 02 / 2003$ & 65.01 & 11.18 & 1.51 & 0.43 & 0.63 & 96.62 & 124.29 & 4.03 \\
$30 / 04 / 2003$ & 59.32 & 8.75 & 1.31 & 0.41 & 0.77 & 77.50 & 127.71 & 4.17 \\
$17 / 07 / 2003$ & 70.30 & 8.75 & 1.66 & 1.09 & 1.37 & 89.59 & 108.43 & 4.36 \\
$03 / 09 / 2003$ & 72.71 & 7.29 & 1.82 & 0.45 & 0.95 & 110.92 & 125.02 & 4.64 \\
\hline
\end{tabular}

Table 6: Chemical analysis of groundwater concerned by the study

\begin{tabular}{|c|c|c|c|c|c|c|c|c|c|c|c|c|c|c|c|c|}
\hline Campione & Data & $\mathrm{pH}$ & $\mathrm{T}\left({ }^{\circ} \mathrm{C}\right)$ & $\begin{array}{l}\text { EC at } \\
25^{\circ} \mathrm{C} \\
\left(\mu \mathrm{S} \mathrm{cm}^{-1}\right)\end{array}$ & $\begin{array}{l}\text { TH } \\
\left({ }^{\circ} \mathrm{f}\right)\end{array}$ & $\begin{array}{c}\mathrm{Na}^{+} \\
(\mathrm{mg} \\
\left.\mathrm{L}^{-1}\right)\end{array}$ & $\begin{array}{l}\mathrm{K}^{+} \\
(\mathrm{mg} \\
\left.\mathrm{L}^{-1}\right)\end{array}$ & $\begin{array}{l}\mathrm{Ca}^{2+} \\
(\mathrm{mg} \\
\left.\mathrm{L}^{-1}\right)\end{array}$ & $\begin{array}{l}\mathrm{Mg}^{2+} \\
(\mathrm{mg} \\
\left.\mathrm{L}^{-1}\right) \\
\end{array}$ & $\begin{array}{l}\mathrm{Cl}^{-} \\
(\mathrm{mg} \\
\left.\mathrm{L}^{-1}\right)\end{array}$ & $\begin{array}{l}\mathrm{NO}_{3}^{-} \\
\left(\mathrm{mg}^{-}\right. \\
\left.\mathrm{L}^{-1}\right)\end{array}$ & $\begin{array}{l}\mathrm{SO}_{4}{ }^{2-} \\
(\mathrm{mg} \\
\left.\mathrm{L}^{-1}\right)\end{array}$ & $\begin{array}{l}\mathrm{HCO}_{3}^{-} \\
(\mathrm{mg} \\
\left.\mathrm{L}^{-1}\right)\end{array}$ & $\begin{array}{l}\text { TDS } \\
(\mathrm{mg} \\
\left.\mathrm{L}^{-1}\right)\end{array}$ & $\begin{array}{l}\mathrm{Mg}^{2+} / \\
\mathrm{Ca}^{2+}\end{array}$ & $\begin{array}{l}\mathrm{SO}_{4}{ }^{2-} / \\
\mathrm{HCO}_{3}\end{array}$ \\
\hline $\mathrm{C} 1$ & Jan 2005 & 7.84 & 7.9 & 1633 & 101.6 & 2.31 & 1.87 & 361.12 & 27.72 & 0.56 & 0.25 & 869.40 & 134.91 & 1398.14 & 0.127 & 8.187 \\
\hline $\mathrm{C} 2$ & Jan 2005 & 7.87 & 7.9 & 1882 & 121.7 & 2.38 & 2.02 & 435.67 & 31.36 & 0.58 & 0.20 & 1060.80 & 137.22 & 1670.24 & 0.119 & 9.820 \\
\hline $\mathrm{C} 3$ & Jan 2005 & 7.01 & 6.3 & 346 & 17.9 & 1.14 & 0.46 & 65.33 & 3.89 & 2.49 & 4.77 & 7.19 & 204.10 & 289.38 & 0.098 & 0.045 \\
\hline SA & Oct 2006 & 6.38 & 6.2 & 330 & 16.8 & 3.91 & 2.28 & 50.90 & 9.94 & 1.04 & 0.10 & 13.96 & 194.64 & 276.78 & 0.322 & 0.091 \\
\hline SA & Jul 2008 & 7.48 & 6.3 & 365 & 18.3 & 2.50 & 0.97 & 70.16 & 1.93 & 1.11 & 2.77 & 9.98 & 206.17 & 295.59 & 0.045 & 0.062 \\
\hline SA2 & Oct 2006 & 6.66 & 6.4 & 290 & 15.0 & 3.15 & 1.73 & 51.29 & 5.36 & 0.71 & 1.26 & 4.73 & 181.89 & 250.11 & 0.172 & 0.033 \\
\hline SA2 & Jul 2008 & Obser & vation we & ell that was & destroyed & uring th & e works. & & & & & & & & & \\
\hline SB & Oct 2006 & 6.90 & 5.6 & 337 & 17.0 & 1.97 & 0.97 & 64.77 & 1.99 & 0.23 & 0.46 & 8.76 & 197.81 & 276.96 & 0.051 & 0.056 \\
\hline SB & Jul 2008 & 7.96 & 9.0 & 287 & 15.4 & 1.05 & 0.75 & 59.19 & 1.42 & 0.50 & 0.99 & 6.13 & 177.45 & 247.47 & 0.040 & 0.044 \\
\hline SB & Jul 2007 & 7.90 & 8.9 & 297 & 15.5 & 0.98 & 1.00 & 60.02 & 1.36 & 1.40 & 1.28 & 14.56 & 174.62 & 255.21 & 0.037 & 0.106 \\
\hline $\mathrm{SC}$ & Oct 2006 & 6.40 & 5.2 & 375 & 18.7 & 1.88 & 0.94 & 73.09 & 1.19 & 0.48 & 2.21 & 6.47 & 217.28 & 303.54 & 0.027 & 0.038 \\
\hline $\mathrm{SC}$ & Jul 2008 & 7.36 & 7.5 & 288 & 15.9 & 1.20 & 0.38 & 59.95 & 2.31 & 0.51 & 3.39 & 5.77 & 176.90 & 250.40 & 0.063 & 0.041 \\
\hline $\mathrm{SC}$ & Jul 2007 & 7.40 & 7.4 & 379 & 18.3 & 1.86 & 2.98 & 71.62 & 1.06 & 2.80 & 2.72 & 13.51 & 206.36 & 302.89 & 0.024 & 0.083 \\
\hline SI3 & Dec 2004 & 7.60 & 7.5 & 264 & 13.6 & 5.39 & 0.91 & 48.10 & 3.89 & 4.78 & 1.81 & 5.61 & 165.78 & 236.25 & 0.133 & 0.043 \\
\hline SI3 & Oct 2006 & 6.69 & 6.0 & 258 & 14.5 & 1.00 & 0.26 & 52.13 & 3.65 & 0.32 & 2.75 & 2.31 & 173.65 & 236.05 & 0.115 & 0.017 \\
\hline SI3 & Jul 2008 & Dry & & & & & & & & & & & & & & \\
\hline Tenda Spring & Dec 2004 & 7.85 & 6.0 & 440 & 22.6 & 2.09 & $<0.01$ & 76.15 & 8.75 & 0.82 & 4.20 & 127.27 & 119.10 & 338.39 & 0.189 & 1.357 \\
\hline Tenda Spring & Oct 2006 & 6.38 & 7.2 & 447 & 23.4 & 1.36 & 0.36 & 89.59 & 2.48 & 0.55 & 2.00 & 118.41 & 124.78 & 339.53 & 0.046 & 1.206 \\
\hline Tenda Spring & Jul 2008 & 7.84 & 7.1 & 371 & 19.6 & 1.21 & 0.40 & 68.61 & 6.09 & 0.89 & 2.86 & 81.95 & 135.35 & 297.36 & 0.146 & 0.769 \\
\hline Tenda Spring & Jul 2007 & 7.82 & 7.1 & 484 & 24.3 & 1.05 & 2.03 & 84.05 & 7.96 & 1.94 & 2.50 & 132.69 & 131.48 & 363.70 & 0.156 & 1.282 \\
\hline $\mathrm{T} 2$ & Dec 2004 & 8.10 & 4.0 & 373 & 16.5 & 12.39 & 1.10 & 57.72 & 5.11 & 17.91 & 4.41 & 12.83 & 187.50 & 298.96 & 0.146 & 0.087 \\
\hline
\end{tabular}

The fluorometer installed at the Colle di Tenda Spring operated continuously for over two months. During this period there was no record of tracer arrival at the spring. Non-arrival of the dye could be related to reduced groundwater flow and significant dispersion and diffusion of the dye itself in the extensive saturated zone of the system feeding the spring, or to reduced water circulation in the rock actually monitored by the observation wells.

Chemical properties of the groundwater: In 2003 samples of water were taken from the Sorgente di Tenda in different periods, which were characterised by a range of hydrodynamic situations. The results of chemical analysis are shown in Table 5.

The data show that the spring water is characterised as bicarbonate-sulphate-calcic in periods of high flow, but it becomes sulphate-bicarbonatecalcic in periods of low flow. A high sulphate level is probably linked with evaporite levels present at the base of the carbonate succession. The sulphate/bicarbonate ratio is subject to variations that are well correlated with the hydrodynamic regime. As a matter of fact decreased flow is followed by an increase in the above ratio, caused by an increase in sulphate level, as against a lesser change in bicarbonate content.

In December 2004, water samples were taken from the Sorgente di Tenda, at the water inflows from the present road tunnel (T2) and at observation well SI3 situated at the ski slopes at $1400 \mathrm{~m}$ a.s.l. Table 6 shows the results of analysis.

The analysis shows that the water from the Sorgente di Tenda is substantially different from the water from sources T2 and SI3, with a mineral content that is both quantitatively and qualitatively different, as is also well demonstrated by the characteristic $\mathrm{Mg}^{2+} / \mathrm{Ca}^{2+}$ ratios and most of all, by the $\mathrm{SO}_{4}{ }^{2-} / \mathrm{HCO}_{3}{ }^{-}$ratio. 
Am. J. Environ. Sci., 7 (1): 1-14, 2011

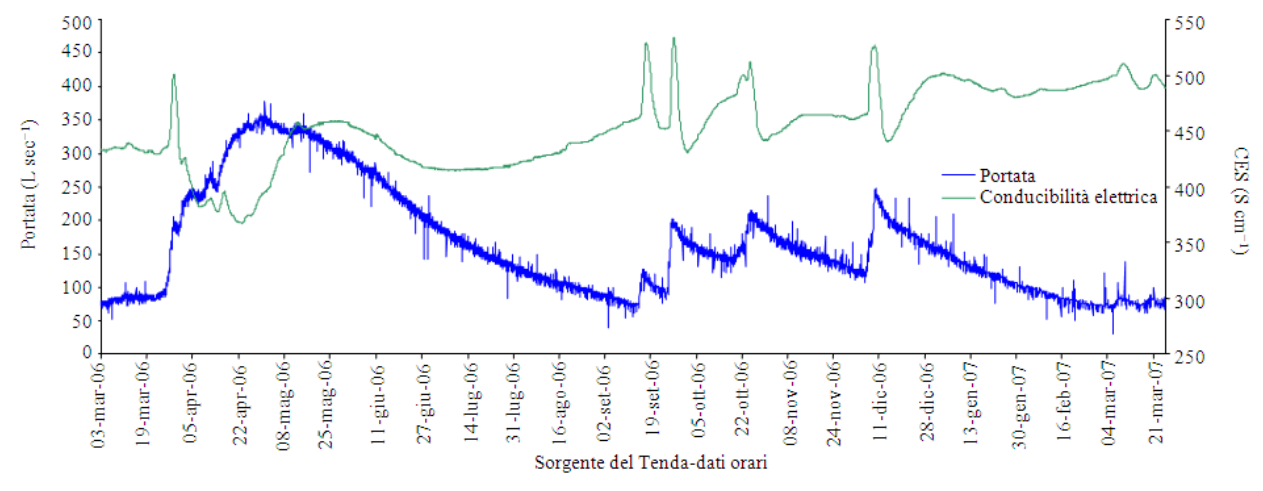

Fig. 11: Variation in temperature (on the left) and electrical conductivity of the water, measured continuously (Dec. '05-Dec. '06)

This, therefore, seems to confirm that the spring water has a sulphate-bicarbonate-calcic facies, which can be linked to groundwater circulation that, in addition to the carbonate formation, also involves levels rich in chalk, anhydrite and "Carniola" (vacuolar limestone), which are probably situated at the principal thrust plane between the upper carbonate formation and the lower Flysch formation. These differences seem to be mainly related to the water time of travel in the carbonate aquifer, which is longer for the Spring than that of observation well SI3 and of the water inflows in the road tunnel.

Subsequently (January 2005) the main water inflows found in the present tunnel were sampled, in particular those at distances $73 \mathrm{~m}$ ( $\mathrm{C} 3$ for the morainic-drift formation), $2856 \mathrm{~m}$ ( $\mathrm{Cl}$ for the evaporite formation) and $2871 \mathrm{~m}$ (C2 for the evaporite formation).

Comparison of the analytical results for the two practically simultaneous field tests makes it possible to state that $\mathrm{C} 3$ (morainic-drift formation) and T2 (main inflow in the tunnel on the Italian side) are very similar (the presence of alkaline chlorides in $\mathrm{T} 2$ can be associated with salt-spreading on the tracks). Sample SI3 indicates a bicarbonate-calcic facies while the Sorgente di Tenda shows a sulphate-bicarbonate-calcic facies although both are members of the same hydrogeological complex (upper Carbonate). Samples $\mathrm{C} 1$ and $\mathrm{C} 2$ in the sulphate-calcic facies indicate circulation related to the Carniola horizons of the evaporatic aquifer that is totally independent of the one feeding the Sorgente di Tenda.

The data for observation wells SA, SA2, SB and SC also show chemical facies that are markedly different from those of the Sorgente di Tenda.

Comparison of flow and temperature behaviour of the spring (Fig. 8) shows substantially constant temperature values between a maximum of $7.40^{\circ} \mathrm{C}$ and a minimum of $7.05^{\circ} \mathrm{C}$ and hence an annual variation of approx. $0.35^{\circ} \mathrm{C}$. This data shows that the direct contribution of newly infiltrated water is secondary: in the springtime, when snow melt is particularly important and there is infiltration of very low temperature water, the effect at the spring is only a mild decrease in temperature, which always stays above $7^{\circ} \mathrm{C}$.

The value of electrical conductivity of the water, over the whole observation period (Fig. 8), shows more marked variations that are directly linked with flow behaviour. In order to highlight these properties, the data for measurements taken over one year have been considered (Fig. 11). Sudden increases in conductivity during the initial stage of flood are shown clearly and these are followed by equally rapid decreases, which indicate a piston action associated with the arrival of water of relatively high mineral content present in the aquifer. The peak is followed by a temporary decrease in conductivity for which the minimum generally corresponds with peak flood. This decrease is not related to the direct arrival of newly percolated water, which is characterised by its very low mineral content, but rather by groundwater contributions arriving from different sections of the water-bearing structure under examination. As already stated, water with varying mineral content, in particular as regards sulphate levels, arrives at the spring, from different sections of the area feeding the spring itself. During the depletion period subsequent to flood further increases and decreases in mineral content can be observed and these are always associated with contributions from different sectors of the water-bearing structure.

Vulnerability of the Sorgente di Tenda and protection zones: Using the flow rate monitoring data, the vulnerability to pollution of the spring has been evaluated, using the Maximum Discharge Half Time (MDHT) method (Civita, 2008). 
Am. J. Environ. Sci., 7 (1): 1-14, 2011

Table 7: Specific hydrodynamic parameters for the spring, based on simulation models

\begin{tabular}{llllllllll}
\hline Depletion & $\mathrm{Q}_{\mathrm{MAX}}\left(\mathrm{m}^{3} \mathrm{sec}^{-1}\right)$ & $\mathrm{Q}_{\mathrm{R} 0}\left(\mathrm{~m}^{3} \mathrm{sec}^{-1}\right)$ & $\alpha$ & $\mathrm{W}_{0}\left(\mathrm{Mm}^{3}\right)$ & $\Delta \mathrm{W}\left(\mathrm{Mm}^{3}\right)$ & $\mathrm{T}_{\mathrm{r}}(\%)$ & $\mathrm{t}_{\mathrm{mr}}(\mathrm{y})$ & $\mathrm{DT}(\mathrm{d})$ & $\mathrm{T}_{\mathrm{D}}(\mathrm{d})$ \\
\hline May '06-Sep. '06 & 0.31 & 0.26 & 001 & 2.32 & 1.70 & 74 & 1.33 & 75 & 65 \\
Dec '06- Mar.'07 & 0.21 & 0.18 & 0.01 & 1.27 & 0.81 & 64 & 1.61 & 81 & 44 \\
\hline
\end{tabular}

Table 8: Values of turbidity, $\mathrm{pH}$, Electrical Conductivity, $\mathrm{Al}^{3+}$ and $\mathrm{Cr}^{6+}$ in the cement-water solutions

\begin{tabular}{|c|c|c|c|c|c|}
\hline $\begin{array}{l}\text { Cement/water } \\
\text { concentration }\left(\mathrm{g} \mathrm{L}^{-1}\right)\end{array}$ & $\begin{array}{l}\text { Turbidity } \\
\text { (NTU) }\end{array}$ & $\mathrm{pH}$ & $\begin{array}{l}\text { Elecctrical Conductivity } \\
\text { at } 20^{\circ} \mathrm{C}\left(\mu \mathrm{S} \mathrm{cm}^{-1}\right)\end{array}$ & $\mathrm{Cr}^{6+}\left(\mu \mathrm{g} \mathrm{L}^{-1}\right)$ & $\mathrm{Al}^{3+}\left(\mu \mathrm{g} \mathrm{L}^{-1}\right)$ \\
\hline 0.00 & 0.06 & 8.00 & 399 & $<1.0$ & 7.9 \\
\hline 0.01 & 1.48 & 8.05 & 395 & $<1.0$ & 30.9 \\
\hline 0.05 & 10.90 & 8.32 & 372 & $<1.0$ & 60.7 \\
\hline 0.10 & 41.22 & 8.65 & 331 & $<1.0$ & 48.3 \\
\hline 0.20 & 90.96 & 9.45 & 287 & 1.5 & 97.9 \\
\hline 0.25 & 121.63 & 10.54 & 322 & 1.5 & 83.6 \\
\hline 0.30 & & 10.75 & 370 & 2.9 & 96.8 \\
\hline 0.40 & & 11.08 & 510 & 4.1 & 153.8 \\
\hline 0.50 & & 11.26 & 668 & 5.0 & 185.6 \\
\hline 1.00 & & 11.56 & 1074 & 8.1 & 541.5 \\
\hline
\end{tabular}

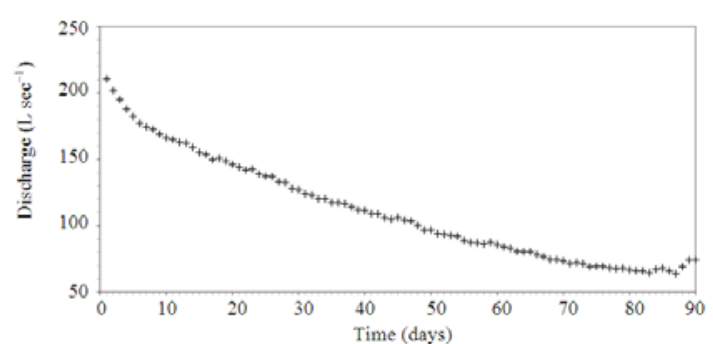

(a)

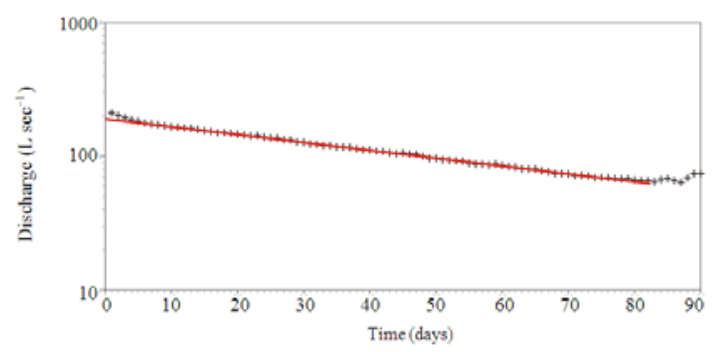

(b)

Fig. 12:(a) Depletion curve for the Sorgente di Tenda (Dec. '06-Mar. '07); (b) Linearisation of the hydrograph

Examination of the spring outflow curves that were recorded between the end of 2005 and June 2008 has given a better understanding of the characteristics of the spring system and of the behaviour of the aquifer feeding it.

The rising curves show no extraordinary features apart from the influence of delayed precipitation (snow) that breaks up the continuity, as is normal in high altitude feed areas and as conductivity behaviour shows.

The simulation model for the falling/depletion (recession) curves, applied to the relevant parts of the 2006-07 hydrographs (Fig. 12), provides much more information.
The first of the two curves initially indicates a system that is highly influenced by delayed infiltration (snow melt) and only more than one month after annual peak flow rate does scarcely influenced depletion begin. The whole depletion curve seems to be "stepped" by little parasite flood that are generally reabsorbed in short spaces of time. These little parasite flood can be interpreted as discharge from small circuits moving at faster rates (karst conduits, broader fractures). These phenomena are also found, although to a lesser extent, during the 2007 depletion that, however, seems to be hardly affected overall.

The hydrodynamic parameters calculated for the two curves are given in Table 7, using an exponential model (Maillet, 2010), rather than later more complex approaches (Civita, 2008).

From the calculations it seems clear that, irrespective of the maximum values, the depletion coefficient $(\alpha)$ is practically the same in the two cases. The values of $\alpha$ have rather high absolute values for a fractured karst aquifer, probably because of the low volume of the recharge area. On the other hand, the minimum flow values ("base flow", auth.) are relatively high, as if a transfer from another water body under pressure is also contributing to spring feed; this hypothesis is also supported by the relative increase in conductivity and temperature corresponding with the end of depletion.

The effective annual reserve $\left(\mathrm{W}_{0}\right)$ is relatively high in relation to flow rates, as is the drainage capacity index $(\Delta \mathrm{W})$. Renewal rate is evidently high and average renewal time $\left(t_{m r}\right)$ is hence short. Delay time, although calculated for only one year's data, indicates a situation at risk: if the aquifer were not fed for a period of the order of 2 months, the spring would be completely depleted, although this event has never actually occurred. 
Am. J. Environ. Sci., 7 (1): 1-14, 2011

Using the inferred half-time values (65 and 44 days), the aquifer under examination is found to have medium to low vulnerability. The spring protection zone, as required by Piedmont Regional law (Regional Regulations No. 15/R of 11th December 2006), under the least favourable conditions (medium vulnerability in this case) should have the following dimensions by (Civita, 2008):

Immediate Protection Zone (IMPZ): resembling a rectangle that, with respect to the tapping point, is $20 \mathrm{~m}$ long upstream, plus $5 \mathrm{~m}$ downstream, with a width of 15 $\mathrm{m}$ (called the "d" limit);

Inner Protection Zone (IPZ): Resembling an upturned trapezoid that is oriented according to the local direction of flow of the aquifer, the lesser base coinciding with the theoretical "d" limit downstream of the IPZ, opening with sides at an angle of at least $30^{\circ}$ with respect to the edges of the IPZ, while the upstream is edge is marked by an arc of circle centred at the centre of the IPZ and having a radius of $400 \mathrm{~m}$.

The construction works are hence found to be outside the protection zones system of the Sorgente di Tenda, being at a distance of at least $575 \mathrm{~m}$ from the tapping works.

Risk of qualitative deterioration: Since the new tunnel is already at the final project design stage, in order to estimate the possible impact of excavations just the same, data have been collected from two construction sites for important underground works. These sites interfere with the aquifer and preventive consolidation is planned, using cement mortar. Although these works are in unconsolidated rock, the comparative situations will certainly be useful for prognosis purposes. For the two aforementioned sites water samples were taken both upstream and downstream. Chemical analysis covered all the chemical-physical parameters covered by Italian Legislative Decree DL 31/01 concerning water drinkableness, in particular with regard to substances such as acrylamide and vinyl chloride. In addition, the most abundantly used substances, because of their low cost, were considered, as well as cement mixtures with admixtures (such as set accelerators or retarders, plasticisers), sodium silicate-based mixtures, resins. These substances may have varying degrees of toxicity. Under hydrogeological conditions such as those of Col di Tenda, it is possible that use of cement mortar, in the excavation sector involving the carbonate aquifer in particular, could cause arrival of turbidity at the spring, with a significant increase in $\mathrm{pH}$, hence precluding water utilisation without specific extra treatment.
Laboratory simulations were therefore carried out, limiting the field to the impact potential of cement and resin injections into groundwater intended for human consumption.

For resins, the results of previous release-to-water tests were taken. These tests had been carried out by authorised laboratories (in compliance with Italian DM 05/02/08) on the mineral-organic product, Global Foam SP. This product is one of a series of resins with similar chemical structure but different degrees of expansion. Consolidation with cement mixtures does take place in similar situations, but using mixture supplements that may release a series of active ingredients to the water, which would arrive simultaneously with the cement solutions. The study focussed on the latter in order to find a series of chemical-physical parameters that would be easy to monitor continuously at the spring, so as to prevent polluted water reaching the consumer.

Different quantities of cement were added to some samples of water taken from the Sorgente di Tenda $\left(0.01,0.05,0.1,0.2,0.25,0.3,0.4,0.5,1 \mathrm{~g} \mathrm{~L}^{-1}\right)$. Turbidity, $\mathrm{pH}$, electrical conductivity and concentrations of $\mathrm{Cr}^{6+}$ and $\mathrm{Al}^{3+}$ ions were then measured (Table 8).

Turbidity was measured using a turbiditimeter that was immersed in the previously shaken water sample for one minute.

The graph in Fig. 13 shows the existence of a relationship between the two parameters. The meter is already able to detect water turbidity at even low cement concentrations. At $0.05 \mathrm{~g} \mathrm{~L}^{-1}$ colour changes to the water are invisible to the naked eye, but the instruments already detect a significant difference, of the order of 10 NTU, compared to the "clear" sample.

However, monitoring turbidity alone is insufficient for demonstrating the presence of cement and admixtures in suspension in the aquifer. Therefore, the effects of cement at low concentrations on $\mathrm{pH}$, on electrical conductivity and on $\mathrm{Al}^{3+}$ and $\mathrm{Cr}^{6+}$ content have been studied under the assumption that a cross-comparison of the results for these five parameters will improve the likelihood of detecting the arrival of very low concentrations of cement at the spring and consequently, of substances that could be dissolved in the water, originating from the mixtures used in the cement.

Addition of cement to spring water generates the formation of an alkaline mixture, caused by the release of the calcium, sodium and potassium hydroxides present in Portland-type cement. The results of chemical analysis of the cement/water solutions are shown in Table 8 and in Fig. 14.

The value of $\mathrm{pH}$ tends to increase as concentration increases. 
Am. J. Environ. Sci., 7 (1): 1-14, 2011

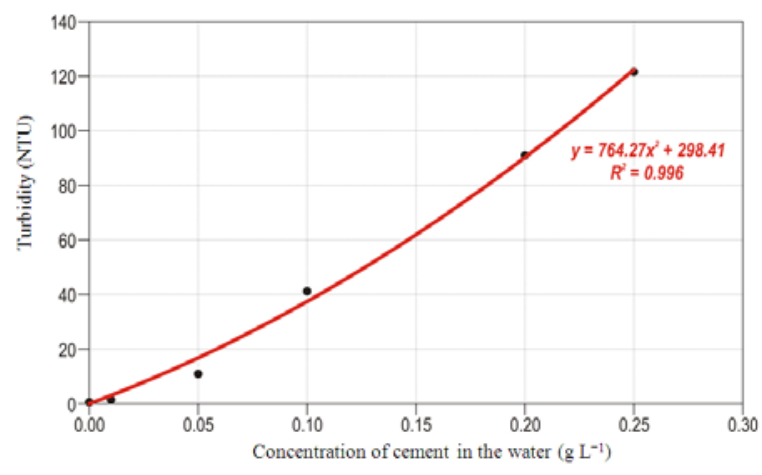

Fig. 13: Graph showing turbidity against concentration of cement in water
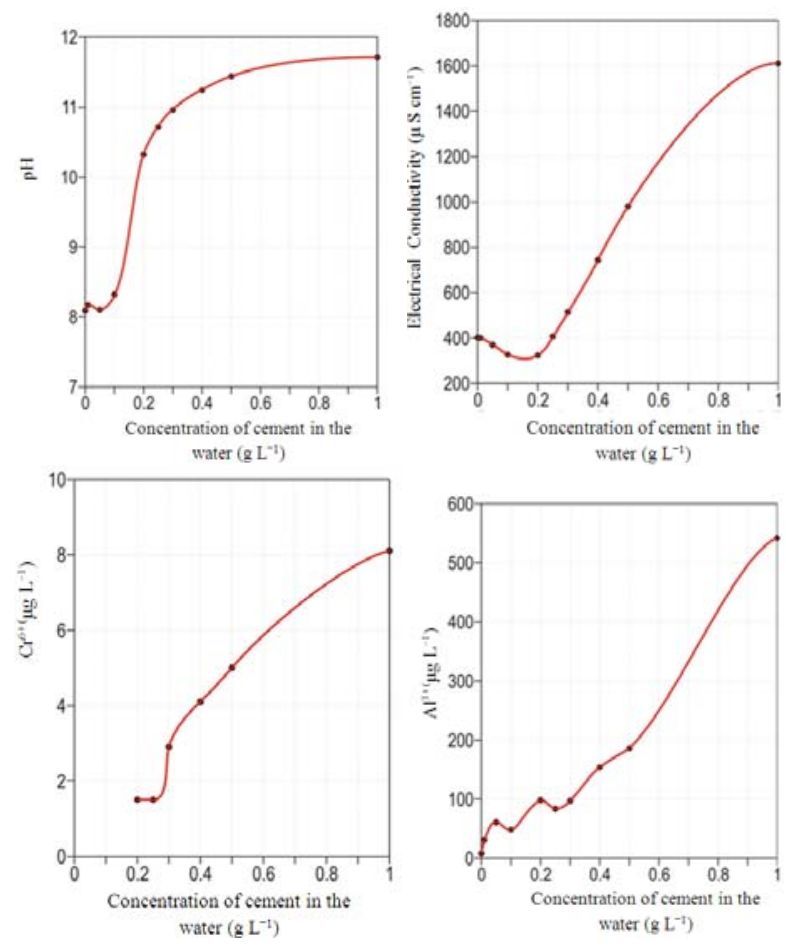

Fig. 14:Graph showing the parameters under consideration as functions of concentration of cement in water

Italian law DL of 2 February 2001 N. 31 rules that for "water intended for human consumption" the $\mathrm{pH}$ must fall between 6.5 and 9.5. It should be noted that the "clear" water sample taken from the spring has a $\mathrm{pH}$ of 8.00 .

While there are no significant changes in $\mathrm{pH}$ for concentrations of up to $0.1 \mathrm{~g} \mathrm{~L}^{-1}$ cement in water, at a concentration of $0.2 \mathrm{~g} \mathrm{~L}^{-1}$ the $\mathrm{pH}$ is already greater than 9.40 and continues to increase, reaching 11.56 at $1 \mathrm{~g}$
$\mathrm{L}^{-1}$. Between 0.1 and $0.2 \mathrm{~g} \mathrm{~L}^{-1}$, therefore, a sudden increase in $\mathrm{pH}$ is observed. Below $0.1 \mathrm{~g} \mathrm{~L}^{-1}$ the changes are neither very significant nor such as to be unambiguously attributable to anthropic activity.

As regards conductivity, the "clear" sample of spring water gave a value of $399 \mu \mathrm{S} \mathrm{cm}$. When cement was added in the quantities listed above, the values of electrical conductivity tended first to decrease to a value of $287 \mu \mathrm{S} \mathrm{cm}^{-1}$ at concentrations of $0.2 \mathrm{~g} \mathrm{~L}^{-1}$ and then increase quite rapidly in a linear fashion to a value of $1074 \mu \mathrm{S} \mathrm{cm}^{-1}$ at concentrations of $1 \mathrm{~g} \mathrm{~L}^{-1}$. The initial decreases in conductivity, for cement concentrations below $0.2 \mathrm{~g} \mathrm{~L}^{-1}$ can be attributable to precipitation of $\mathrm{CaCO}_{3}$, which occurs due to the addition of the calcium oxide component of the cement. This phenomenon continues until the $\mathrm{CO}_{3}{ }^{2-}$ ion is completely removed and then, for subsequent levels of added cement, the electrical conductivity increases according to the ion contribution from the cement itself.

To complete the study, concentrations of $\mathrm{Cr}^{6+}{\mathrm{e} \mathrm{Al}^{3+}}^{3+}$ were measured. These chemical parameters should also be monitored almost continuously, even though this presents more difficulties, in order to detect the arrival of active ingredients resulting from the use of mixtures.

Italian law (Leg. decree DL 31/01) rules that, for water intended for human consumption, aluminium concentration must not exceed $200 \mu \mathrm{g} \tilde{\mathrm{L}}^{-1}$. Such concentrations of aluminium can be found in water containing $0.5 \mathrm{~g} \mathrm{~L}^{-1}$ cement in suspension, while for concentrations of $1 \mathrm{~g} \mathrm{~L}^{-1}$ the aluminium reaches values well above $500 \mu \mathrm{g} \mathrm{L}^{-1}$.

As regards $\mathrm{Cr}^{+6}$, which has been recognised as a human carcinogen, cement that is to be sold and used may not release chrome to water in quantities greater than $0.0002 \%\left(2 \mu \mathrm{g} \mathrm{L}^{-1}\right)$ hydrosoluble $\mathrm{Cr}^{+6}$ of the total dry weight of the cement, when placed in water.

Italian legislation sets two different limits for $\mathrm{Cr}^{+6}$ concentrations in the aquifer. In a rather contradictory manner, Italian D.L. 3/4/2006 No.152 sets a limit of 5 $\mu \mathrm{g} \mathrm{L}^{-1} \mathrm{Cr}^{+6}$ for groundwater (without expressing intended use), while the aforementioned D.L. 2/2/2001 No.31 sets a limit of $50 \mu \mathrm{g} \mathrm{L}^{-1}$ total chrome in water intended for human consumption. This means it will be necessary to plan tests on the chosen cements, taking account of the particular chemical properties of the actual groundwater present.

On the basis of the results taken from the records and from the experiments described above, it seems probable that excavation of the new tunnel could have a significant impact potential on the water resource that is tapped in the railway tunnel underneath. However, recent research on alternative materials is able to provide interesting solutions for the case under examination. 
Am. J. Environ. Sci., 7 (1): 1-14, 2011

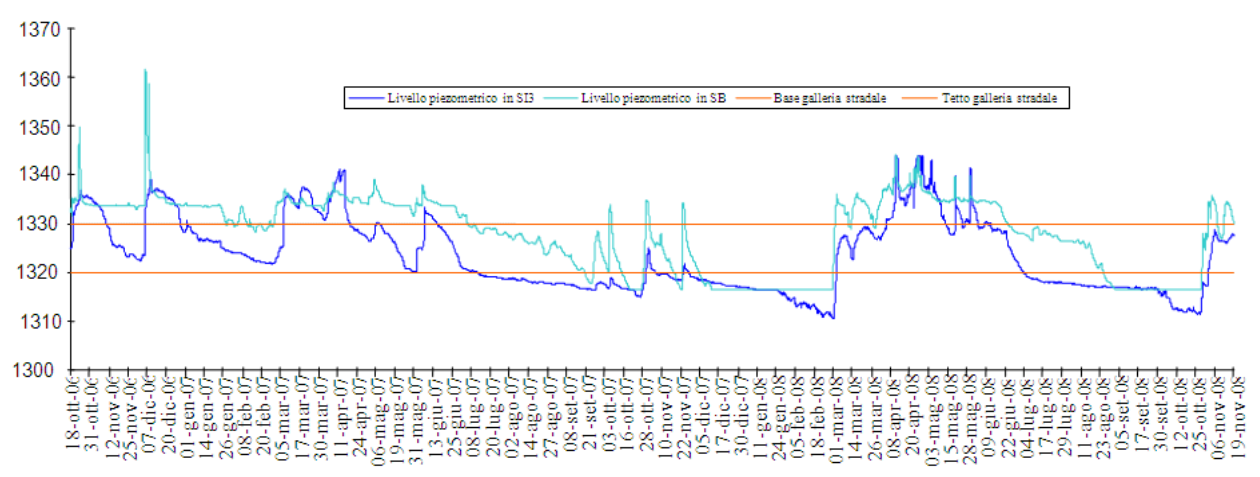

Fig. 15: Variation of piezometric levels in monitoring wells SI3 and SB (Oct. '06-Nov. '08)

These new materials form the latest generation of mineral-organic resins: pure single- or dual-component solutions with low viscosity and relatively high reaction rates. These properties make them particularly suitable barriers against abundant water flows. Their singlestage nature means that these solutions are able to penetrate porous media, to reach even low permeability media. There are, for example, products currently on the market that have been widely tested for consolidation and waterproofing of fractured and karstified rock masses. When subjected to a series of water release tests complying with UNI standards, these types of product are completely atoxic and do not release toxic substances to the water, except in very low concentrations that are in any case well below the limits set by the legislation.

Expected arrival times: In order to be able to forecast the arrival time of a potential contaminant flow to the spring, a range of speeds have been considered, inferred from tests carried out on fractured limestone, in the Alpi Liguri, that has a similar hydrogeological structure. To measure the distance between the spring and the overlying aquifer, which is affected by excavation of the road tunnel, the following points were considered: the furthest $(900 \mathrm{~m})$ and the nearest $(575$ $\mathrm{m})$ points of the stretch of tunnel that crosses the carbonate aquifer $(254.6 \mathrm{~m})$ and the spring tapping works ( $60 \mathrm{~m}$ long). Based on the estimates, the speeds range from $5 \times 10^{-5}-2.5 \times 10^{-2} \mathrm{~m} \mathrm{sec}^{-1}$. Assuming a hydraulic gradient of 0.44 for the area under examination, the respective permeability values for the carbonate mass are found to fall between $2.2 \times 10^{-5}$ $\mathrm{m} \mathrm{sec}^{-1}$ and $1.1 \times 10^{-2} \mathrm{~m} \mathrm{sec}^{-1}$, which is typical of a rock mass with a range of fractured states and related karstification.

For relatively high permeability values, it is possible to hypothesise relatively short arrival times at the spring for a possible contaminant coming from the carbonate portions involved in the road tunnel consolidation works. Given the well-logging data and the fractured state of the observed carbonate mass, in the study area it is possible to hypothesise permeability of between $10^{-3}$ and $10^{-4} \mathrm{~m} \mathrm{sec}^{-1}$ with arrival times of between 7 and 67 days.

Risk of quantitative deterioration: Water level monitoring records for the carbonate aquifer that will be affected by the new tunnel (Fig. 15) show that the excavation will undergo different pressure head conditions. During the winter and late summer the piezometric level of the aquifer will be below the excavation level, while during substantial flows (snow melt or abundant precipitation) the hydraulic head may reach as many as thirty metres above road level.

The route of the new tunnel is at the same altitude and at about $20 \mathrm{~m}$ away from the previous excavation; therefore, significant differences between the work under construction and the existing tunnel are not expected. Nevertheless, it was considered necessary to calculate the drainage potential of the new work because, given that the inflow/outflow equilibrium of the hydrogeological structure is fixed, water drawdown may lessen the quantity of water tapped at the spring.

In order to forecast the drawdown that excavation of the new tunnel may cause, thus depriving the spring, model was used. This seems to be the most suitable model for the particular circumstances.

The parameter settings for the model are based on known average permeability values $\left(\mathrm{K}=10^{-3} \mathrm{~m} \mathrm{sec}^{-1}\right)$ for the mass, considered as a non-indurate equivalent; dominant hydraulic head $(27 \mathrm{~m})$; an excavation radius of $9 \mathrm{~m}$ with a stretch in aquifer of $254.6 \mathrm{~m}$. A flow rate of $\sim 0.024 \mathrm{~m}^{3} \mathrm{sec}^{-1}$ is obtained for the whole stretch. These values correspond more or less with the flows drained from the existing tunnel during periods of particularly heavy precipitation. 
Am. J. Environ. Sci., 7 (1): 1-14, 2011

Table 9: Proposed threshold values for monitoring the Sorgente di Tenda at the construction stage

\begin{tabular}{llll}
\hline Parameter & $\begin{array}{l}\text { Legal limits } \\
\text { Italian Law D.L. 02.02.01 No.31) }\end{array}$ & $\begin{array}{l}\text { Recommended } \\
\text { Threshold Value }\end{array}$ & $\begin{array}{l}\text { Corresponding water- } \\
\text { cement concentration }\end{array}$ \\
\hline Turbidity & $\begin{array}{l}\text { Not required by the legislation, } \\
\text { but considered to be below 1 NTU }\end{array}$ & $0.50 \mathrm{NTU}$ & $\sim 0.005 \mathrm{~g} \mathrm{~L}^{-1}$ \\
$\mathrm{pH}$ & $\begin{array}{l}6.5<\mathrm{pH}<9.5 \\
\text { Electrical conductivity }\end{array}$ & 9 & $\sim 0.12 \mathrm{~g} \mathrm{~L}^{-1}$ \\
\hline
\end{tabular}

The risk of impoverishing spring flow will therefore be extremely low, during periods of drought in particular and flow will be scarcely influenced during spring floods that reach values even exceeding $0.3 \mathrm{~m}^{3}$ $\mathrm{sec}^{-1}$. It should be pointed out that the future works will be completely waterproofed.

Monitoring: Given the many problems that have arisen in similar situations, at the expense of local water resources, careful monitoring should be carried out at every stage of the works:

- monitoring before works start

- monitoring during construction

- monitoring after works completion

Always assuming that spring flow rate must be measured continuously during the works and for a long period after their conclusion, the highly important monitoring stage before works start has been carried out by following the behaviour of numerous parameters in different sectors of the area under examination and for a number of years, in order to characterise the aquifer as precisely as possible and to understand hydrodynamic and chemical-physical variations over time and the possible responses to stress of man-made origin. The work has made it possible to formulate numerous considerations of an environmental nature and at the decision stage, will make it possible to take the correct technical decisions so as to prevent the occurrence of public health, economic and strategic problems and should it be necessary, to close the Sorgente di Tenda if the arrival of contaminants is detected.

Monitoring during construction is essential in order to keep a check on water quality at the spring during the various stages of the works. The purpose of the following study was also to identify which parameters, of those with values that are easy to record continuously, would be able to indicate the arrival of undesirable substances at the spring, as a result of consolidation works on the tunnel.

Monitoring during construction is hence of fundamental importance in the prevention of public health emergencies related to this important, valuable water resource. The instruments that are to be installed at the spring must be able to carry out continuous monitoring of parameters such as turbidity, $\mathrm{pH}$, electrical conductivity and flow rate. For a range of parameters, alarm thresholds have been defined so that when a threshold is crossed the water is immediately sampled, by an automatic sampling machine connected to the recorders, for complete chemical analysis in order to check for the presence of undesirable substances. If the maximum allowed concentration is reached it will be necessary to take immediate steps to stop water input to the aqueduct.

Table 9 shows some threshold values that have been identified for the three parameters (turbidity, $\mathrm{pH}$ and electrical conductivity) that are the easiest to determine at a reasonable cost and that give sufficiently valid overall readings as indicators of the potential arrival of undesirable substances at the spring.

The threshold value for turbidity should take account of turbidity occurring in springtime, which is related to snow melt and reaches levels of approx. 60 NTU. Clouding of the water due to low concentration injections of cement solutions, which at other times of the year would be clearly visible, would remain unnoticed in springtime. For this reason, parallel monitoring of a practically constant aquifer parameter, like $\mathrm{pH}$, is proposed. As a matter of fact, slight increases of $\mathrm{pH}$ are able to detect the arrival at the spring of solutions with low cement concentrations.

The last parameter to be monitored is specific electrical conductivity. The water from the Sorgente di Tenda never reaches conductivity values that exceed $550 \mu \mathrm{sm}^{-1}$ and peak values are only observed at the time of heavy precipitation or snow melt. Minimum recorded values are always greater than $350 \mu \mathrm{s} \mathrm{cm}^{-1}$. The plan is for tunnel excavations to be carried out in the limestone portion during drought periods, when water levels in the aquifer have a lower hydraulic head and hence create fewer difficulties during excavation. These periods coincide with seasons of low rainfall (winter or summer) when water conductivity shows fairly constant values (around $400 \mu \mathrm{s} \mathrm{cm}^{-1}$ ).

Any (positive or negative) changes in the value of this parameter during dry periods and when spring output is low could reasonably be attributed to the arrival of substances dissolved in the water as a result of consolidation works in the road tunnel above the spring. 
Continuous monitoring and cross-comparison of the various parameters (turbidity, $\mathrm{pH}$, conductivity and flow rate) are able to indicate, with sufficient certainty, any pollutants that may arrive at the spring.

Monitoring after works completion has the same characteristics and purpose as monitoring during construction. At this stage it will also be necessary to keep a check on phenomena due to leaching of sulphated water present in the Col di Tenda aquifer, which may affect the injected cement, now-solidified, solutions.

\section{DISCUSSION}

This case study presents an infrequently occurring situation. An Alpine massif, where there are already two tunnels (for road and rail traffic) requires further excavation to double the existing heavily trafficked road tunnel link between Italy and France.

The uniqueness of the case is the presence, inside the rail tunnel, of a highly important spring that feeds a very extensive aqueduct system serving 1a00,000 inhabitants of a territory with scarce available water resources for human consumption.

The problem has been tackled before inauguration of the construction site, with a precise prognosis of the hydrogeological scenario based on readings, installation of monitoring wells, continuous level and flow measurements, chemical analysis of the water, tracer tests.

Reconstruction of the scenario has made it possible to provide indications for the new excavation, above all in order to reduce to a minimum the risk of spring contamination caused by percolation of cement and hazardous admixtures.

It has also been possible to estimate the vulnerability of the spring in terms of the requirements of Italian law D.L. 152/2006 regarding protection zones for water intended for human consumption.

\section{CONCLUSION}

The study is concluded by specific requirements and recommendations for monitoring the spring water during and subsequent to the construction works.

\section{REFERENCES}

Civita, M., G. Peano and B. Vigna, 1982. La stazione sperimentale della Grotta di Bossea nel quadro delle ricerche idrogeologiche sui sistemi carsici del Monregalese. Mem. Soc. Geol. It., 29: 187-207.

Civita, M., M. De Maio and B. Vigna, 1999. Una metodologia GIS per la valutazione della ricarica attiva degli acquiferi. Atti $3^{\circ}$ Convegno Nazionale Sulla Protezione E Gestione Delle Acque Sotterranee I Parma, 1: 1.291-1.303.

Civita, M.V., 2008. An improved method for delineating source protection zones for karst springs based on analysis of recession curve data. Hydrogeol. J., 16: 855-869. DOI: 10.1007/s10040008-0283-4

Maillet, E.T., 2010. Essais D'Hydraulique Souterraine and Fluviale. 1st Edn., BiblioBazaar, USA., ISBN10: 1146093268, pp: 282. 